\title{
Phi29 polymerase based random amplification of viral RNA as an alternative to random $R T-P C R$
}

\author{
Nicolas Berthet ${ }^{1,2}$, Anita K Reinhardt ${ }^{1}$, India Leclercq ${ }^{3,4}$, Sven van Ooyen ${ }^{5}$, \\ Christophe Batéjat ${ }^{3}$, Philip Dickinson ${ }^{6}$, Rayna Stamboliyska1, Iain G Old ${ }^{7}$, \\ Katherine A Kong ${ }^{6}$, Laurent Dacheux ${ }^{8}$, Hervé Bourhy8, Giulia C Kennedy, \\ Christian Korfhage ${ }^{5}$, Stewart T Cole ${ }^{9}$ and Jean-Claude Manuguerra*3
}

\begin{abstract}
Address: ${ }^{1}$ Genotyping of Pathogens and Public Health Technological Platform, Institut Pasteur, Paris, France, ${ }^{2}$ Oncogenic Virus Epidemiology and Pathophysiology Unit, Institut Pasteur, Paris, France, ${ }^{3}$ Laboratory for Urgent Response to Biological Threats (CIBU), Institut Pasteur, Paris, France, ${ }^{4}$ Université Paris 7 Denis Diderot, Paris, France, ${ }^{5}$ Qiagen, Hilden, Germany, ${ }^{6}$ Affymetrix, Santa Clara, CA, USA, ${ }^{7}$ European Office, Institut Pasteur, Paris, France, ${ }^{8}$ Lyssavirus dynamics and host adaptation Unit, Institut Pasteur, Paris, France and ${ }^{9}$ Bacterial Molecular Genetics Unit, Institut Pasteur, Paris, France

Email: Nicolas Berthet - nberthet@pasteur.fr; Anita K Reinhardt - reinhard@pasteur.fr; India Leclercq - ileclerc@pasteur.fr; Sven van Ooyen - Sven.vanOoyen@qiagen.com; Christophe Batéjat - cbatejat@pasteur.fr; Philip Dickinson - Philip_Dickinson@affymetrix.com; Rayna Stamboliyska - raynas@pasteur.fr; Iain G Old - iain.old@epfl.ch; Katherine A Kong - Katie_Kong@affymetrix.com; Laurent Dacheux - Idacheux@pasteur.fr; Hervé Bourhy - hbourhy@pasteur.fr; Giulia C Kennedy - Giulia_Kennedy@affymetrix.com; Christian Korfhage -Christian.Korfhage@qiagen.com; Stewart T Cole - stewart.cole@epfl.ch; Jean-Claude Manuguerra* - jmanugu@pasteur.fr

* Corresponding author
\end{abstract}

Published: 4 September 2008

BMC Molecular Biology 2008, 9:77 doi:10.1186/147I-2199-9-77

This article is available from: http://www.biomedcentral.com/I47/-2/99/9/77

(C) 2008 Berthet et al; licensee BioMed Central Ltd.

This is an Open Access article distributed under the terms of the Creative Commons Attribution License (http://creativecommons.org/licenses/by/2.0), which permits unrestricted use, distribution, and reproduction in any medium, provided the original work is properly cited.

\begin{abstract}
Background: Phi29 polymerase based amplification methods provides amplified DNA with minimal changes in sequence and relative abundance for many biomedical applications. RNA virus detection using microarrays, however, can present a challenge because phi29 DNA polymerase cannot amplify RNA nor small cDNA fragments ( $<2000$ bases) obtained by reverse transcription of certain viral RNA genomes. Therefore, ligation of cDNA fragments is necessary prior phi29 polymerase based amplification. We adapted the QuantiTect Whole Transcriptome Kit (Qiagen) to our purposes and designated the method as Whole Transcriptome Amplification (WTA).
\end{abstract}

Results: WTA successfully amplified cDNA from a panel of RNA viruses representing the diversity of ribovirus genome sizes. We amplified a range of genome copy numbers from 15 to $4 \times 10^{7}$ using WTA, which yielded quantities of amplified DNA as high as $1.2 \mu \mathrm{g} / \mu \mathrm{l}$ or $10^{10}$ target copies. The amplification factor varied between $10^{9}$ and $10^{6}$. We also demonstrated that co-amplification occurred when viral RNA was mixed with bacterial DNA.

Conclusion: This is the first report in the scientific literature showing that a modified WGA (WTA) approach can be successfully applied to viral genomic RNA of all sizes. Amplifying viral RNA by WTA provides considerably better sensitivity and accuracy of detection compared to random RT-PCR. 


\section{Background}

Parallelization of nucleic acid sequence detection requires a sufficient quantity (in the microgram range) of DNA for subsequent hybridization-based methods such as those using DNA microarrays or resequencing arrays. For RNA virus detection, target DNA represents the amplified product of reverse transcription (RT). RT and DNA amplification can be achieved either by using primers specific for relevant viruses or by random priming. Although random priming can amplify an unknown target, it often yields lower amounts of DNA than specific primers, which can reduce the overall sensitivity of the process. Multiple Displacement Amplification (MDA) using bacteriophage phi29 polymerase with random primers allows DNA synthesis in amounts compatible with the downstream use of DNA microarrays [1]. Moreover, MDA has the potential to amplify the whole DNA genome (whole genome amplification, WGA) of target pathogens in the presence of contaminating DNA. WGA technology has become a useful upfront amplification method for many biomedical applications, such as microsatellite analysis, single nucleotide polymorphism (SNP) detection and comparative genomic hybridization (CGH) to microarrays. We recently showed that WGA can now be used for DNA viral pathogen detection from clinical samples using resequencing microarrays [2]. Indeed, resequencing technology using microarrays is very promising for bacterial and viral pathogen detection and identification, as well as for the determination of their pathogenicity profile [2-5]. However, MDA cannot be used to amplify RNA nor small cDNA obtained from RNA genomes after reverse transcription or small native DNA fragments such as those generated by RT from segmented riboviral genomes. Therefore, MDA has not been previously used with riboviruses. A novel modified MDA approach by Qiagen designated QuantiTect Whole Transcriptome has been developed for Transcriptome studies. We changed the process by using a different reverse transcription strategy containing random primers instead of a mixture of random and oligo-dT primers and a different reverse transcriptase. In this WTA process, after reverse transcription of RNA utilizing random primers, all cDNAs are being ligated together into longer linear chains allowing concatenated cDNAs from small RNA fragments to be used as templates for MDA. We applied WTA to viral RNA and demonstrated that WTA is applicable for CDNA amplification of a whole range of RNA virus genomes, prior to DNA hybridization based techniques. About half a dozen approaches have been developed for random whole genome amplification upstream of SNP detection methods (e.g. Omniplex ${ }^{\circledast}$ technology [6], DOP-PCR $[7,8]$, LAPCR $[9,10]$, PCR with universal linker [11] and T7 based linear amplification for genomic DNA [12]). Among them, WGA and Random Amplification (RA) based on random RT and random PCR are the most widespread techniques for the detection and identification using DNA microarrays. In this study, we chose to compare WTA and RA. The final DNA yields generated by RA and by WTA, in the absence or presence of prokaryotic DNA, were evaluated by quantitative PCR (qPCR). The accuracy of identification by high-density microarrays was also compared between RA and WTA processes.

\section{Methods \\ RNA extraction}

Total RNA from brain biopsies (5-10 mg) were obtained using $1 \mathrm{ml}$ of TRI Reagent (Molecular Research Center) according to the manufacturer's instructions. Other RNA extraction was performed using QIAamp Viral RNA Mini Kit (Qiagen) according to the manufacturer's instructions.

\section{Synthesis of viral RNA complementary strand}

The complementary strand (cDNA) of extracted viral RNA was performed in a $200 \mu \mathrm{l}$ tube. The primer used for RA was described by Wang et al [13] whereas cDNA synthesis for WTA was performed with random hexamer primers at the same concentration except for the influenza $\mathrm{B}$ virus experiment where the final concentration was diluted 10fold. A mix with $8 \mu \mathrm{l}$ of RNA, $1 \mu \mathrm{l}$ of primer $(50 \mu \mathrm{M})$ and $1 \mu \mathrm{l}$ of dNTPs $\left(10 \mathrm{mM}\right.$ ) was incubated at $75^{\circ} \mathrm{C}$ for $5 \mathrm{~min}$, cooled on ice for $5 \mathrm{~min}$. Then, $10 \mu \mathrm{l}$ of $2 \times$ enzyme mix were added. This enzyme mix was composed of $2 \mu \mathrm{l}$ of 10 $\times$ RT Buffer for SSIII (Invitrogen Inc.), $4 \mu \mathrm{l}$ of $25 \mathrm{mM}$ $\mathrm{MgCl}_{2}, 2 \mu \mathrm{l}$ of $0.1 \mathrm{M} \mathrm{DTT}, 1 \mu \mathrm{l}$ of $40 \mathrm{U} / \mu \mathrm{l}$ RNaseOUT (Invitrogen Inc.), $1 \mu$ l of Reverse Transcriptase SuperScript III (Invitrogen Inc.) and $0.5 \mu \mathrm{l}$ of DMSO (Sigma-Aldrich). The final mix was submitted to the following steps: $25^{\circ} \mathrm{C}$ for $10 \mathrm{~min}, 45^{\circ} \mathrm{C}$ for $90 \mathrm{~min}$ and $95^{\circ} \mathrm{C}$ for $5 \mathrm{~min}$. All cDNAs were stored at $-20^{\circ} \mathrm{C}$ or immediately used.

\section{Viral RNA amplification based on the Random Amplification method (RA)}

After the synthesis of the complementary strand, a secondstrand DNA synthesis was carried out with the addition of $10 \mu \mathrm{l}$ of Klenow mix, consisting of $3 \mu \mathrm{l}$ of $10 \times$ Klenow Buffer, $2 \mu \mathrm{l}$ of dNTP (0.5 mM each) and $1 \mu \mathrm{l}$ of Klenow DNA polymerase I (Biolabs). The final $30 \mu \mathrm{lmix}$ was incubated at $20^{\circ} \mathrm{C}$ for $20 \mathrm{~min}$ and at $95^{\circ} \mathrm{C}$ for $5 \mathrm{~min}$. Subsequently, $15 \mu \mathrm{l}$ of the resulting double stranded DNA was used as template for a 40 cycle PCR with Primer E as previously described by Wang et al [13] except the addition of $0.5 \mu \mathrm{l}$ of DMSO and the use of TaKaRa DNA polymerase $(5 \mathrm{U} / \mu \mathrm{l})$ instead of Taq DNA polymerase.

\section{Viral RNA amplification based on "Whole Transcriptome Amplification" kit (WTA)}

Viral RNA amplification was performed as described in the protocol of the QuantiTect Whole Transcriptome Kit (Qiagen) except for the cDNA synthesis step. It was replaced by the reverse transcription protocol as described 
above. The two following steps were performed according to the manufacturer's instructions (Qiagen).

\section{Co-amplification of RNA and DNA pathogens}

The amplification of viral RNA and bacterial DNA as mentioned above was based on the WTA amplification process as described above except that, after the ligation step, a nucleic acid denaturation was performed by adding $2 \mu \mathrm{l}$ of denaturating solution available in Repli-g MIDI kit (Qiagen) and incubated for $3 \mathrm{~min}$ at room temperature. After that, the final amplification step was performed according to the manufacturer's instructions (Qiagen).

\section{Identification and quantification by RT-qPCR for Rift Valley Fever Virus}

To identify Rift Valley Fever Virus (RVFV), RT-qPCR was performed with the primers published by Drosten et al. [14] but using LC RNA Amplification kit SYBRGreen I (Roche Diagnostic) and different RT and PCR cycling conditions. The detection and quantification involved the following steps: reverse transcription at $55^{\circ} \mathrm{C}$ for $10 \mathrm{~min}$, initial denaturation at $95^{\circ} \mathrm{C}$ for $30 \mathrm{~s}$, and 45 cycles with $95^{\circ} \mathrm{C}$ for $5 \mathrm{~s}$ and $72^{\circ} \mathrm{C}$ for $10 \mathrm{~s}$. Fluorescence was read at the combined annealing-extension step at $72^{\circ} \mathrm{C}$.

\section{Identification and quantification by qPCR for Staphylococcus aureus}

The LightCycler instrument (Roche Diagnostics) was used to amplify a $197 \mathrm{bp}$ region of the $S$. aureus nucA gene with LC FastStart DNA MasterPLUS SYBRGreen kit. PCR was performed in a total volume of $20 \mu \mathrm{l}$ containing $4 \mu \mathrm{l}$ of Master mixture including Taq polymerase, reaction buffer, and a deoxynucleoside triphosphate mixture; $10.6 \mu \mathrm{l}$ of pure water and $0.5 \mu \mathrm{M}$ each of forward (5' GACTATTATTGGTTGATACACCTG 3') and reverse (5' GCCTTGACGAACTAAAGCTTC 3') primers. After distribution of $15 \mu \mathrm{l}$ of the master mixture, $5 \mu$ l of diluted template DNA solution was added to each glass capillary (Roche Diagnostics), centrifuged, and placed in the LightCycler sample carousel. LightCycler amplification involved a first denaturation at $95^{\circ} \mathrm{C}$ for $10 \mathrm{~min}$, followed by amplification of the target DNA for 50 cycles $\left(95^{\circ} \mathrm{C}\right.$ for $10 \mathrm{~s}, 53^{\circ} \mathrm{C}$ for 20 $\mathrm{s}$, and $72^{\circ} \mathrm{C}$ for $10 \mathrm{~s}$ ) with a temperature transition rate of $20^{\circ} \mathrm{C} / \mathrm{s}$. The fragment amplification step is followed by a melting curve analysis to an increase from $50^{\circ} \mathrm{C}$ to $95^{\circ} \mathrm{C}$ at a rate of $0.1^{\circ} \mathrm{C} / \mathrm{s}$.

\section{Quantification of amplified DNA}

After purification, the DNA obtained was quantified using "Qubit Quantitation Platform" either with the Quant-iT dsDNA HS Assay/Quant-iT dsDNA BR Assay kits for DNA or the Quant-iT RNA Assay kit for RNA as recommended by the manufacturer (Invitrogen ${ }^{\circledast}$ ).

\section{Hybridization to microarrays}

DNA amounts obtained after amplification were quantified by Quantit BR and Quantit HS (Invitrogen Inc.), for WTA and RA, respectively. The same quantity of DNA was fragmented (GeneChip ${ }^{\circledR}$ Resequencing Assay Kit, Affymetrix Inc.) and labelled according to the GeneChip ${ }^{\circledR}$ Mapping $100 \mathrm{~K}$ Assay Manual (Affymetrix Inc.). Microarray hybridization was conducted at $45^{\circ} \mathrm{C}$ and array processing was carried out according to the protocol recommended by the manufacturer (Affymetrix Inc.) as previously described [2]. All experiments described in these studies were carried out using independent duplicates.

\section{Data Analysis}

The raw image file (.DAT) obtained after scanning the microarray was analyzed using the Affymetrix GeneChip Operating Software (GCOS) to produce a simplified file format (.CEL) with intensities assigned to each of the corresponding probe positions. Next, the Affymetrix GeneChip Sequence Analysis Software (GSEQ), which contains a derivative of the ABACUS algorithm [15], uses the probe intensities to call the bases along genetic fragments included on the microarray, outputting the result in a FASTA file. The analysis parameters were optimized in order to obtain the best call rate value while minimising the rate of resequencing error. The call rate for a fragment is simply the ratio of called bases to the total number of bases expressed as a percentage. More details concerning data analysis are described in Berthet et al [2].

\section{Results \\ DNA yields and amplification factors for WTA and RA}

Phi29 polymerase requires DNA templates larger than 2 $\mathrm{kb}$, which exceeds the size of the smallest RNA strands of segmented RNA viruses (e.g. influenza viruses). To address this shortcoming, a target cDNA ligation step is performed prior to MDA amplification resulting in the WTA protocol. In this work, WTA was compared to a RA protocol as described in the Material and Methods (M\&M). The DNA yields obtained using WTA and RA methods were compared for three different viral RNA genomes. We tested (i) a viral genome fragmented into small segments (influenza B virus: $14 \mathrm{~kb}$ and 8 segments), (ii) a fragmented middle size genome (Rift Valley Fever Virus (RVFV): $12 \mathrm{~kb}$ and 3 segments) and (iii) a large viral genome (Severe Acute Respiratory Syndrome CoronaVirus (SARS-CoV): $29 \mathrm{~kb}$ and 1 segment), which are representative of the extreme diversity in RNA viral genome size. WTA DNA yields were $1.21 \pm 0.06 \mu \mathrm{g} / \mu \mathrm{l}, 0.98 \pm 0.27$ $\mu \mathrm{g} / \mu \mathrm{l}$ and $1.42 \pm 0.08 \mu \mathrm{g} / \mu \mathrm{l}$, respectively. These yields greatly exceed those observed with RA $(0.02 \pm 0.01 \mu \mathrm{g} / \mu \mathrm{l}$, $0.06 \pm 0.02 \mu \mathrm{g} / \mu \mathrm{l}$ and $0.012 \pm 0.004 \mu \mathrm{g} / \mu \mathrm{l}$, respectively) It is noteworthy that, in the absence of a DNA template, water controls amplified by WTA yield as much as $0.9 \mu \mathrm{g} /$ 
$\mu$ of non-specific DNA. This spurious amplification is probably due to priming artefacts or E. coli residual DNA from the production process of one of the kit enzymes. However, in the presence of a DNA template, such as $S$. aureus DNA, the proportion of non-specific DNA dramatically decreases to undetectable levels using previously described DNA microarray techniques [2].

High amplification factors were obtained starting WTA with various viral genome equivalents. When starting WTA with 15 to $4 \times 10^{7}$ copies of RVFV RNA genome copies, the WTA amplification factor ranged from $10^{9}$ to $10^{6}$ whereas the RA factor varied from $10^{3}$ to $10^{1}$ respectively (Figure 1). In comparison with RA, the amplification of viral RNA was extremely high irrespective of the amount of RNA genome input. The sensitivity of the detection and identification protocol, based on resequencing microarray technology, was determined by measuring the lowest number of genome copies in the target applied to the microarray. Figure 2 shows the call rate for the RNA polymerase gene of RVFV expressed as a function of the number of genome copies. The call rate is the percentage of bases called by the resequencing algorithm (see M\&M).
Microarrays required a minimum of $\sim 10^{8}$ viral genome copies for gene detection and identification confirmed by BLAST analysis. The high amplification ratio obtained with WTA allowed the detection of RVFV irrespective of the copy number of input viral RNA into the amplification process. These sensitivity levels are compatible with the viral load found in some clinical samples. In sharp contrast, the low amplification ratio observed with RA is irrelevant in clinical situations as it requires a very high viral load for detection by microarrays, i.e. to obtain the required $\sim 10^{8}$ copies of target sequence for hybridization. To evaluate the potential of WTA in more complex samples where viral RNAs are mixed with cellular RNAs and DNAs, human $(n=2)$, mouse $(n=10)$ and $\operatorname{dog}(n=2)$ rabies-infected brain extracts were tested. After hybridization of WTA amplified material on the DNA chip described previously [2], all samples were found positive for the presence of rabies virus with a minimum call rate of $40 \%$.

\section{Numberof R VFV \\ copies after \\ ant lification me thod}

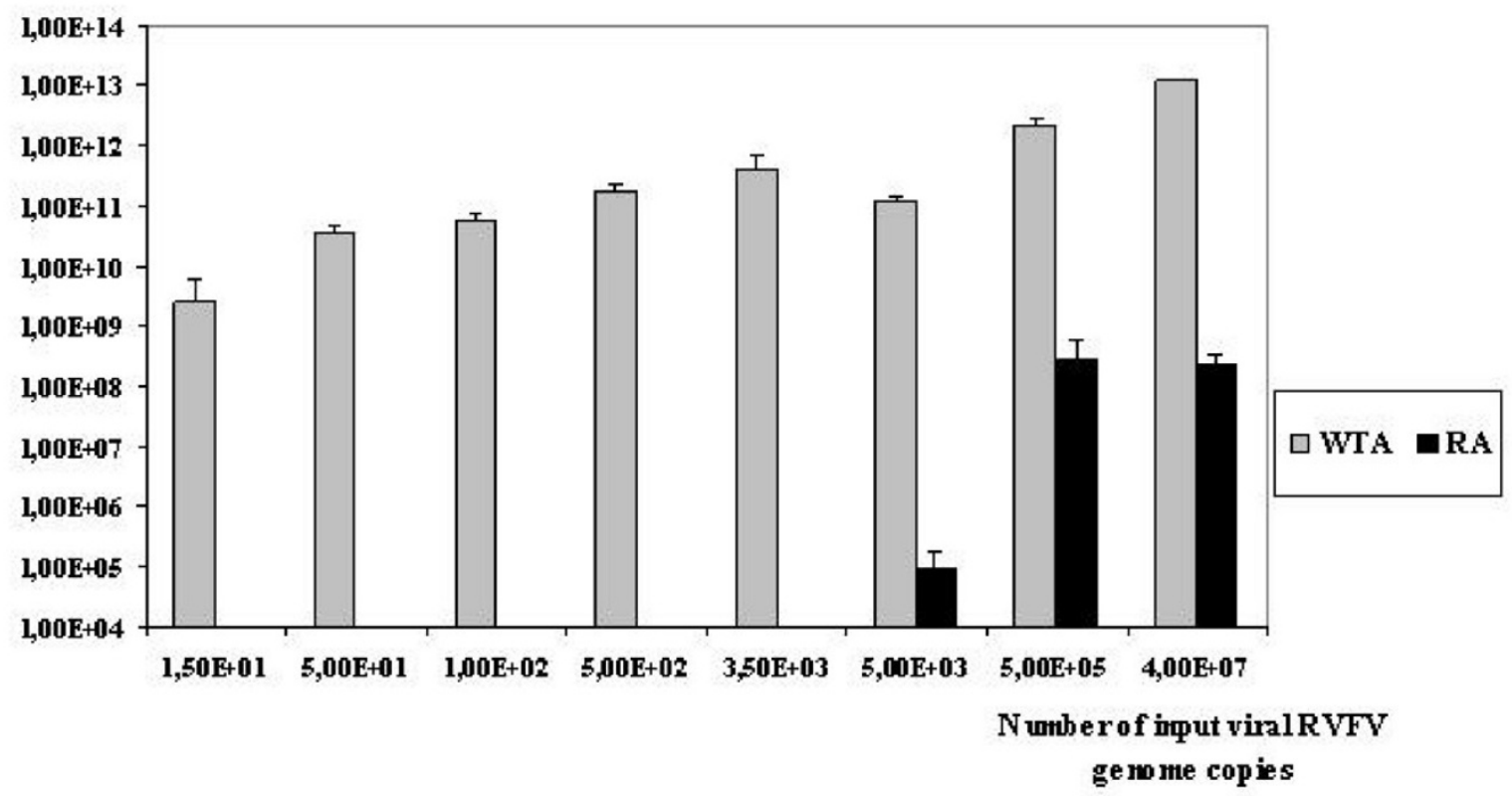

Figure I

Comparison of amplification factor between Whole Transcriptome Amplification (WTA) and Random Amplification (RA) protocols. The number of RVFV copies after amplification is expressed as a function of the amount of input DNA (in number of genome copies). Amounts of RVFV RNA before and after amplification were estimated by qPCR of RVFV as described in M\&M. 


\section{Call rate $(\%)$}

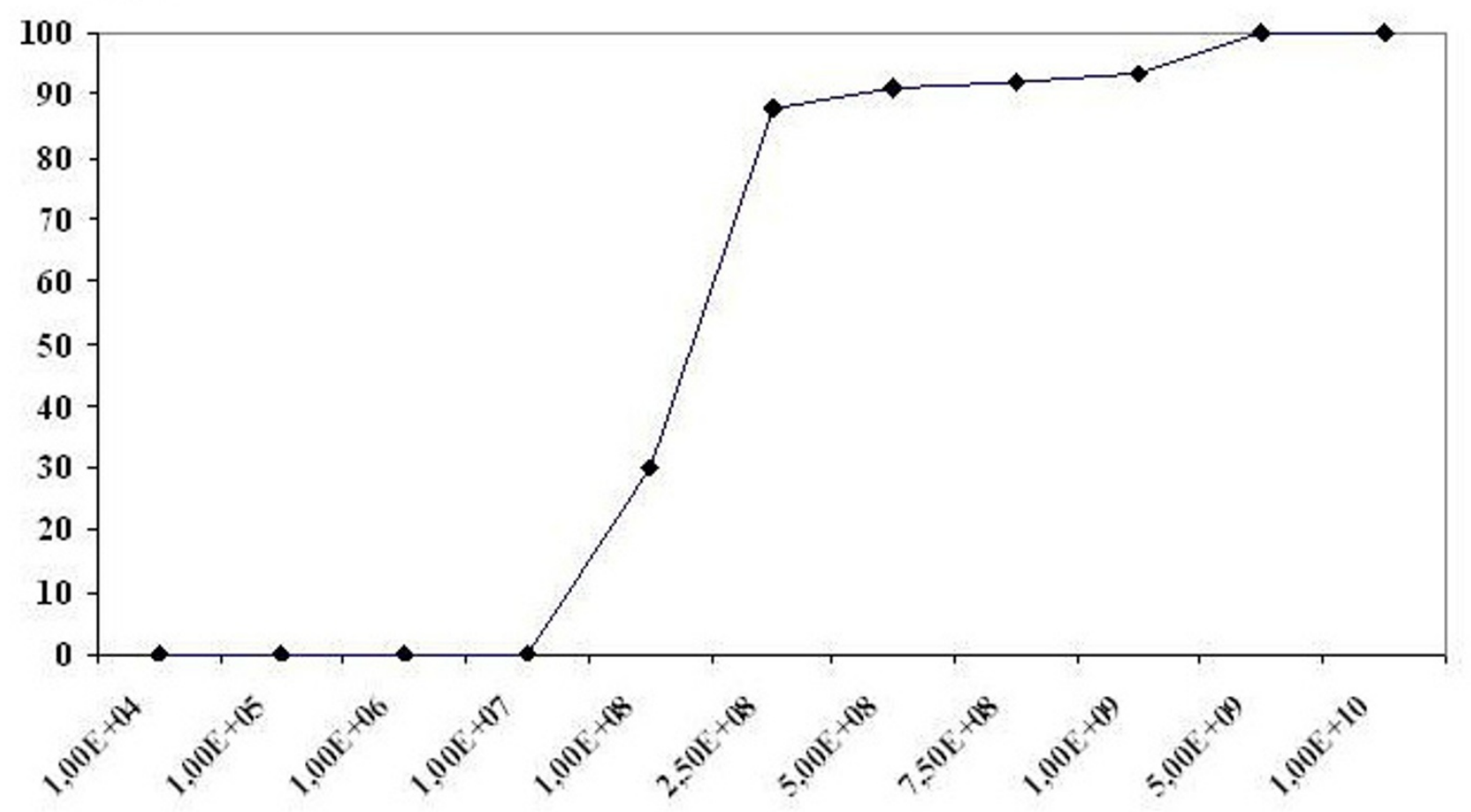

Number of hybridized viral RVFV genome copies

\section{Figure 2}

Mass titration curves with RVFV. The call rates of the RNA polymerase gene from RVFV are expressed as a function of the amount of input DNA (in number of genome copies).

Table I: Call rates for seven different viral RNAs using WTA method.

\begin{tabular}{|c|c|c|c|c|c|}
\hline \multirow{3}{*}{ Viral family } & \multirow{3}{*}{ Name of virus } & \multirow{3}{*}{ Number of fragments (size) } & \multirow{3}{*}{ Strand } & \multicolumn{2}{|c|}{ Whole Transcriptome Amplification } \\
\hline & & & & \multicolumn{2}{|c|}{ Call rate $(\%)$} \\
\hline & & & & Average \pm SD & Range (Min-Max) \\
\hline Coronaviridae & SARS-CoVI & I (2975I) & $\mathbf{S +}$ & $99.1 \pm 0.3$ & (98.9-99.3) \\
\hline \multirow{2}{*}{ Flaviviridae } & Yellow fever & I (I0862) & $\mathbf{S +}$ & $74.4 \pm 2.5$ & $(72.6-76.2)$ \\
\hline & Dengue type 2 & I (I0703) & $\mathbf{S +}$ & $59.4 \pm 10.7$ & $(51.8-66.9)$ \\
\hline \multirow[t]{2}{*}{ Rhabdoviridae } & $\mathrm{VSV}^{2}$ & I (III6I) & S - & $96.8 \pm 2.1$ & $(95.3-98.3)$ \\
\hline & $\mathrm{CVS}^{3}$ & I (II966) & S - & $73.6 \pm 1.1$ & $(72.8-74.3)$ \\
\hline Bunyaviridae & Rift valley fever virus & 3 (12181: 6606*, 3885, 1690) & $\mathbf{S}+/-$ & $100 \pm 0$ & $(100-100)$ \\
\hline Orthomyxoviridae & $\begin{array}{l}\text { Influenza virus type B } \\
\text { (B/Yamagata/l66/98) }\end{array}$ & $\begin{array}{c}8 \\
\left(14289: 2328^{*}, 2352,2273,1843,1793\right. \\
1504,1151,1045)\end{array}$ & S - & $72.3 \pm 9.7$ & $(65.4-79.1)$ \\
\hline
\end{tabular}

I. Severe Acute Respiratory Syndrome Coronavirus

2. Vesicular Stomatitis Virus

3. Rabies virus: Challenge Virus Strain

S+: Positive RNA genome; S-: Negative RNA genome; S+/-: Negative or ambisense RNA genome

* Genome segment partially tiled on this chip 


\section{Hybridization of viral genomes of various lengths with resequencing microarray}

In order to assess the quality of amplified cDNA, hybridization to high density DNA resequencing arrays was performed and the call rate values of the sequences determined through this analysis were compared. To this aim, the viral amplification using WTA was performed with seven viruses representative of the size diversity of viral genomic RNAs, including positive and negative strand genomes as well as non-segmented and segmented genomes (Table 1). These data confirmed that the WTA method amplified viral cDNA from a cell culture supernatant and identified the virus after hybridization. In all cases, virus identification was accomplished using BLAST analysis of DNA sequence determined using the resequencing chip.

\section{Simultaneous amplification of viral RNA and bacterial DNA}

In a previous study, we detected and identified DNA from monkeypox virus and Staphylococcus aureus in a skin lesion collected from a patient [2]. Similarly, we wanted to check whether a co-infection between a RNA virus and $S$. aureus would lead to such discriminating results, bearing in mind that the ratio between the amount of genetic material of RNA virus and bacteria is even higher. We therefore evaluated the influence of RNA and DNA of diverse origins on amplification results. Simultaneous amplification of viral RNA and bacterial DNA was performed using an optimized WTA protocol as described in the M\&M. As shown in Table 2, S. aureus DNA amplification was affected by neither the amount of DNA nor the presence of viral cDNA. Similarly, cDNA from viral RNA was amplified, whatever the quantity of viral genome tested. However, the amplification ratio was decreased in the presence of large quantity of $S$. aureus DNA. Considering the sensitivity threshold for the identification of RVFV (Figure 2), this virus would be identified after hybridization on the DNA chip with a high call rate, i.e. greater than $80 \%$, in all cases shown in Table 2, except for $1.45 \times 10^{4}$ copies of viral RNA and $1.29 \times 10^{6}$ copies of $S$. aureus DNA. Similar results were obtained after the co-amplification of the RVFV cDNA and the DNA of a cowpox virus (data not shown).

\section{Discussion}

WTA allowed amplification of a whole range of RNA viral genomes with high sensitivity thereby providing an accurate and highly effective alternative to other random amplification methods. In this study, we changed the WTA method (QuantiTect Whole-Transcriptome Kit, Qiagen) by using a different reverse transcription step and demonstrated unbiased identification of many different viruses using WTA and oligonucleotide resequencing microarray technology. Two viruses belonging to phylogenetically distinct genera (Vesiculovirus and Lyssavirus) were identified with a call rate of $96.8 \%$ and $73.6 \%$ respectively. However, amplification output may vary within the same viral genus as illustrated with yellow fever and dengue viruses (Flavivirus). The lower call rate obtained for dengue 2 virus might be due to secondary structures in the target sequence, as suggested by the higher call rate obtained with yellow fever virus whose target sequence lacked such structures. These results demonstrate the effect of selected sequences on the final output. As mentioned for the analysis of human, mouse and dog brain samples for the detection of rabies virus, the presence of eukaryotic nucleic acids did not prevent either the amplification using WTA or the downstream identification of the pathogen on DNA microarrays. WTA not only amplified a huge diversity of viral RNAs but also bacterial RNAs such as those transcribed from ribosomal, house-keeping and antibiotic resistance genes, extracted from either a pure bacterial culture or a clinical sample (data not shown). The simultaneous amplification of cDNA from bacterial and viral RNA would be useful for the characterization of many different types of pathogens that cause similar symptoms, such as respiratory syndromes, providing considerable potential for medical use. Samples containing 15 genome copies of viral RNA per target per

Table 2: Co-amplification results of RVFV RNA and S. aureus DNA.

Staphylococcus aureus

\begin{tabular}{|c|c|c|c|}
\hline & Amount input Nucleic Acid & $1.3 \times 10^{4}$ copies & $1.3 \times 10^{6}$ copies \\
\hline & & \multicolumn{2}{|c|}{ Final yield in copies } \\
\hline \multirow[t]{2}{*}{ Rift Valley Fever Virus } & $1.5 \times 10^{4}$ copies & $\begin{array}{l}\text { SA: } 2.1 \pm 0.9 \times 10^{9} \\
\text { RVFV: } 2.1 \pm 0.3 \times 10^{10}\end{array}$ & $\begin{array}{l}\text { SA: } 1.4 \pm 0.1 \times 10^{11} \\
\text { RVFV: } 3.8 \pm 2.7 \times 10^{7}\end{array}$ \\
\hline & $1.5 \times 10^{6}$ copies & $\begin{array}{l}\text { SA: } 8.2 \pm 1.7 \times 10^{8} \\
\text { RVFV: } 1.37 \pm 0.03 \times 10^{11}\end{array}$ & $\begin{array}{l}\text { SA: } 1.4 \pm 0.2 \times 10^{11} \\
\text { RVFV: } 2.5 \pm 0.7 \times 10^{9}\end{array}$ \\
\hline
\end{tabular}

All the quantifications, both before and after amplification, were determined by $Q P C R$ as described in M\&M.

SA: S.aureus 
reaction could be amplified with WTA, to a yield compatible with most of the detection methods used in diagnosis. WTA could thus be used upstream of many pathogen identification protocols for clinical samples (e.g. DNA micro-arrays, liquid DNA arrays, Southern blots, modified qPCR using exonuclease or hybridization probes). DNA polymerization catalyzed by phi29 DNA polymerase is a highly accurate process. Direct sequencing experiments sampling $500000 \mathrm{bp}$ determined its error rate to be $9.5 \times 10^{-6}[16]$, making it one of the most accurate polymerases available.

\section{Conclusion}

WTA thus provides an isothermal alternative to random RT-PCR, and could become an invaluable method in diagnostic applications, particularly when used in conjunction with oligonucleotide microarrays.

\section{Abbreviations}

DOP-PCR: Degenerate Oligonucleotide Primer - PCR; MDA: Multiple Displacement Amplification; LA-PCR: linker-adapter-mediated PCR; RA: Random Amplification; RVFV: Rift Valley Fever Virus; SA: Staphylococcus aureus; SNP: Single Nucleotide Polymorphism; WGA: Whole Genome Amplification; WTA: Whole Transcriptome Amplification.

\section{Competing interests}

The authors declare that they have no competing interests.

\section{Authors' contributions}

NB, AKR, CB, RS and IL carried out molecular studies. NB, IL and JCM participated in experimental design of the study. NB, IL and JCM participated in drafting the manuscript. NB, AKR, CB, PD, IGO, STC, GK, HB, LD and JCM participated in data analysis. SS and CK participated in the development of WTA kit. All authors added corrections and suggestions to the manuscript. JCM conceived and coordinated the study. All authors read and approved the final manuscript.

\section{Acknowledgements}

We thank Qiagen R\&D department members, Drs T. Sattler, S. Rega and A. Takvorian for giving us this early-access version of WTA kit. This work was supported in part by grant number UCI Al0626I3 (Kennedy) from the US National Institute of Allergy and Infectious Diseases, National Institutes of Health. We thank Drs M. Bouloy, D. Coudrier, D. Blondel and P.

Desprès for their kind gift of viral RNA for this study. In the final stage of this work, NB was supported by "Programme Transversal de Recherche" (PTR DEVA ${ }^{\circ}$ 246) from Institut Pasteur.

\section{References}

I. Vora GJ, Meador CE, Stenger DA, Andreadis JD: Nucleic acid amplification strategies for DNA microarray-based pathogen detection. Appl Environ Microbiol 2004, 70(5):3047-3054.

2. Berthet N, Dickinson P, Filliol I, Reinhardt AK, Batejat C, Vallaeys T, Kong KA, Davies C, Lee W, Zhang S, Turpaz Y, Heym B, Coralie G, Dacheux L, Burguière AM, Bourhy H, Old IG, Manuguerra JC, Cole
ST, Kennedy GC: Massively parallel pathogen identification using high-density microarrays. Microbial Biotechnology 2008, I(I):79-86.

3. Lin B, Blaney KM, Malanoski AP, Ligler AG, Schnur JM, Metzgar D, Russell $K L$, Stenger DA: Using a resequencing microarray as a multiple respiratory pathogen detection assay. J Clin Microbiol 2007, 45(2):443-452.

4. Lin B, Vora GJ, Thach D, Walter E, Metzgar D, Tibbetts C, Stenger DA: Use of oligonucleotide microarrays for rapid detection and serotyping of acute respiratory disease-associated adenoviruses. J Clin Microbiol 2004, 42(7):3232-3239.

5. Lin B, Wang Z, Vora G], Thornton JA, Schnur JM, Thach DC, Blaney KM, Ligler AG, Malanoski AP, Santiago J, Walter EA, Agan BK, Metzgar D, Seto D, Daum LT, Kruzelock R, Rowley RK, Hanson EH, Tibbetts C, Stenger DA: Broad-spectrum respiratory tract pathogen identification using resequencing DNA microarrays. Genome Res 2006, 16(4):527-535.

6. Barker DL, Hansen MS, Faruqi AF, Giannola D, Irsula OR, Lasken RS, Latterich M, Makarov V, Oliphant A, Pinter JH, Shen R, Sleptsova I, Ziehler W, Lai E: Two methods of whole-genome amplification enable accurate genotyping across a 2320-SNP linkage panel. Genome Res 2004, I 4(5):901-907.

7. Jordan B, Charest A, Dowd JF, Blumenstiel JP, Yeh Rf RF, Osman A, Housman DE, Landers JE: Genome complexity reduction for SNP genotyping analysis. Proc Natl Acad Sci U S A 2002, 99(5):2942-2947.

8. Telenius H, Carter NP, Bebb CE, Nordenskjold M, Ponder BA, Tunnacliffe A: Degenerate oligonucleotide-primed PCR: general amplification of target DNA by a single degenerate primer. Genomics 1992, 13(3):718-725.

9. Pirker C, Raidl M, Steiner E, Elbling L, Holzmann K, Spiegl-Kreinecker S, Aubele M, Grasl-Kraupp B, Marosi C, Micksche M, Berger W: Whole genome amplification for CGH analysis: Linkeradapter PCR as the method of choice for difficult and limited samples. Cytometry A 2004, 6 I (1):26-34.

10. Zhang L, Cui X, Schmitt K, Hubert R, Navidi W, Arnheim N: Whole genome amplification from a single cell: implications for genetic analysis. Proc Natl Acad Sci U S A 1992, 89(13):5847-585I.

II. Klein CA, Schmidt-Kittler O, Schardt JA, Pantel K, Speicher MR, Riethmuller G: Comparative genomic hybridization, loss of heterozygosity, and DNA sequence analysis of single cells. Proc Natl Acad Sci U S A 1999, 96(8):4494-4499.

12. Liu CL, Schreiber SL, Bernstein BE: Development and validation of a T7 based linear amplification for genomic DNA. BMC Genomics 2003, 4(I):19.

13. Wang D, Coscoy L, Zylberberg M, Avila PC, Boushey HA, Ganem D, DeRisi JL: Microarray-based detection and genotyping of viral pathogens. Proc Natl Acad Sci U S A 2002, 99(24): I5687- I5692.

14. Drosten C, Gottig S, Schilling S, Asper M, Panning M, Schmitz H, Gunther S: Rapid detection and quantification of RNA of Ebola and Marburg viruses, Lassa virus, Crimean-Congo hemorrhagic fever virus, Rift Valley fever virus, dengue virus, and yellow fever virus by real-time reverse transcriptionPCR. J Clin Microbiol 2002, 40(7):2323-2330.

15. Cutler DJ, Zwick ME, Carrasquillo MM, Yohn CT, Tobin KP, Kashuk C, Mathews DJ, Shah NA, Eichler EE, Warrington JA, Chakravarti A: High-throughput variation detection and genotyping using microarrays. Genome Res 200I, II(II): I913-1925.

16. Paez JG, Lin M, Beroukhim R, Lee JC, Zhao X, Richter DJ, Gabriel S, Herman P, Sasaki H, Altshuler D, Li C, Meyerson M, Sellers WR: Genome coverage and sequence fidelity of phi29 polymerase-based multiple strand displacement whole genome amplification. Nucleic Acids Res 2004, 32(9):e7I. 